\title{
Experimental infection of racing pigeons (Columba livia domestica) with highly pathogenic Clade 2.3.4.4 sub-group B H5N8 avian influenza virus
}

Celia Abolnik $^{\mathrm{a}^{*}, \text { Savannah Stutchbury }^{\mathrm{a}} \text {, Marthinus Jacobus Hartman }}{ }^{\mathrm{b}}$

aDepartment of Production Animal Studies, Faculty of Veterinary Science, University of Pretoria, Private Bag X04, 0110, South Africa

bepartment of Companion Animal Clinical Studies, Faculty of Veterinary Science, University of Pretoria, Private Bag X04, Onderstepoort, 0110, South Africa

* Corresponding author

Tel.: +27 12529 8258; Fax: +27 125298306 .

E-mail address: celia.abolnik@up.ac.za 


\section{ABSTRACT}

Reported mass mortalities in wild pigeons and doves during the 2017/2018 Clade 2.3.4.4 HPAI H5N8 outbreaks in South Africa necessitated an investigation of healthy racing pigeons for their susceptibility and ability to transmit a Clade 2.3.4.4 sub-group B virus of South African origin. Pigeons challenged with medium (10 $\left.0^{4.5} \mathrm{EID}_{50}\right)$ and high doses $\left(10^{6}\right.$ $\left.\mathrm{EID}_{50}\right)$ but not a low dose $\left(10^{3} \mathrm{EID}_{50}\right)$ of virus, shed virus in low levels of $<10^{3} \mathrm{EID}_{50} / \mathrm{ml}$ from the oropharynx and cloaca for up to eight days, with peak shedding around 4 days post challenge. Challenged pigeons were able to transmit the virus to contact pigeons, but not contact chickens. Neither pigeons nor chickens presented clinical disease, and only two pigeons in the group that received the high challenge dose developed influenza A-virus specific antibodies. The levels of virus shed by the racing pigeons were well below the published bird infectious dose 50 values for most poultry, especially chickens, therefore the risk that racing pigeons could act as propagators and disseminators through excretion of Clade 2.3.4.4 HPAI H5N8 strains remains negligible.

\section{Highlights}

- A clade 2.3.4.4 HPAI H5N8 sub-group B virus did not cause clinical disease in racing pigeons

- Virus was transmitted to contact pigeons, but not contact chickens

- Virus titers shed by infected pigeons were below the bird infectious dose for most poultry species

Keywords: highly pathogenic avian influenza; clade 2.3.4.4; pigeons; chickens 


\section{INTRODUCTION}

In 1996 a highly pathogenic avian influenza (HPAI) H5N1 virus emerged from the live bird markets of China's Guangdong province whose descendants would eventually cause unprecedented panzootics. The Goose/Guangdong/96 (Gs/Gd/96) H5N1 ancestral virus was lethal to many species including humans and differentiated into genetic lineages or clades that disseminated over vast distances (WHO, 2012). One of these genetic sub-lineages, Clade 2.3.4.4, first appeared around 2014 in Central Asia and became widely dispersed through the Afro-Eurasian waterbird flyway system, eventually reaching sub-Saharan Africa via Palaearctic migrant ducks by November 2016 (Sims et al., 2017). Clade 2.3.4.4 H5 subtype viruses, existing as numerous neuraminidase $(\mathrm{N})$ antigen-type reassortments, for example H5N8 and H5N6, have become adapted to sub-clinical replication in a wide variety of wild avian species, yet cause lethal infections in others, especially gallinaceous birds. Some species of apparently healthy waterfowl are capable of shedding high quantities of the virus into the environment through their fecal and oral secretions (Kang et al., 2017). If susceptible poultry are exposed and become infected, disease can progress rapidly, followed by death within days (Lee et al., 2016 a; Lee et al., 2016b).

Clade 2.3.4.4 HPAI H5N8 reached South Africa with wild migrant birds by July 2017 and multiple spillovers caused localized outbreaks in commercial and backyard poultry, hobby birds and zoological collections. Between July and October 2017, losses to the commercial poultry sector were estimated at R1.66 billion (Abolnik et al., 2018; Davids et al, 2018). Many free-living wild species were also affected, and dead pigeons and doves were often reported on affected poultry farms. H5N8 was confirmed by PCR in at least four dead Laughing doves (Spilopelia senegalensis) and nine African Rock pigeons, also known as the Speckled pigeon (Columba guinea) (OIE, 2018). This contradicted a body of scientific literature detailing experimental infections with the $\mathrm{Gs} / \mathrm{Gd} / 96 \mathrm{H} 5$ lineage that showed that 
pigeons and doves are reasonably resistant to HPAI H5 infection, rarely show clinical signs, and are ineffective shedders of the virus (reviewed in Abolnik, 2014). The unusual die-offs in pigeons and doves during the outbreaks in 2017 in South Africa raised questions about whether the local strains (classified as sub-group B) had altered infection kinetics in pigeons compared to other Clade 2.3.4.4 H5Nx strains from other regions (e.g. Kwon et al 2017). Pigeon racing is a popular international sport, and the Sun City Million Dollar Pigeon Race for example is a prestigious event hosted in South Africa annually in February. The year-long preparation process involves specially-bred imported entrants being placed in quarantine before a vigorous training schedule begins, alongside their locally-bred competitors. Typically racing pigeons from countries hosting active Clade 2.3.4.4 H5Nx outbreaks, for example those in Europe, are subsequently not permitted to enter quarantine in South Africa because of the perceived risk to the local poultry sector.

All prior studies that assessed the pathogenicity and transmissibility of Gs/Gd/96 H5 strains have used wild-caught birds or pigeons sourced from live bird markets or bred for meat (Abolnik, 2014; Kwon et al., 2017; Xiang et al., 2017). Whereas these pigeons appeared clinically healthy and were sero-negative and PCR negative at the time, their prior exposure histories were unknown. Here, we used purpose-bred high quality juvenile racing pigeons with a known microbial status, from a professional loft with no prior influenza virus exposure. We evaluated the susceptibility of healthy racing pigeons to an HPAI H5N8 Clade 2.3.4.4 virus of the B sub-group through low, medium and high challenge doses, and the ability of challenged pigeons to transmit the virus to in-contact pigeons and chickens, in order to assess the risk posed by racing pigeons to the local poultry industry and endangered indigenous wild bird populations. 


\section{MATERIALS AND METHODS}

\subsection{Animals and health status}

Thirty six pure bred racing pigeons aged eleven weeks, identified by numbered leg rings, were enrolled in the study. Pigeons were vaccinated twice against Newcastle disease virus (Nobilis ${ }^{\circledR}$ Paramyxo P201) at three weeks of age and again 26 days later, and once against pigeon pox virus (Medpet MediPox) 17 days after the first paramyxovirus vaccination, with the manufacturers' recommended doses. All pigeons were of good body condition and plumage was free of external parasites and at the early stage of moult in the southern hemisphere. The general health status of all pigeons was determined as follows: individual crop smears were performed by rotating a moistened cotton bud in the crop 2-3 times and examining the droplet under 10x microscopic magnification (Olympus $\mathrm{CH}$ ) for canker (Trichomonas gallinae). Furthermore, crop smears pooled according to small test groups were heat fixed, stained (Diff Quick) and examined for candidiasis (Candida albicans) spores. Individual peripheral blood smears were made from the toe tip, air dried, stained and examined for pigeon malaria (Haemaproteus columbae) under 100x magnification. At least ten high power fields were examined at the periphery of each blood smear and its feathered edge respectively. Pooled feacal samples were examined for roundworm (Ascaridia columbae) and hairworm (Capillaria obsignata) ova and coccidia oocysts (Eimeria columbanum and Eimeria labbeanna) under 10x magnification after flotation. Presence of tapeworm types (Hymenolepsis columbae and Reiliettina columbae) were not determined.

Six specific pathogen free (SPF) White Leghorn Layer type chickens at four weeks of age were purchased from Avifarms (Pty) Ltd, Pretoria. All chickens appeared clinically healthy and were free of anatomical abnormalities. Each chicken was identified individually by 
colour using non-toxic permanent markers on the feathers. Pigeons and chickens were randomly allocated into groups according to the trial schedule. All animal procedures were approved by the University of Pretoria's Animal Ethics Committee.

Birds were housed in three custom-built cages $(1 \mathrm{~m} \times 1 \mathrm{~m} \times 2 \mathrm{~m})$ placed inside a multi-purpose isolation room of the Poultry Biosafety Level 3 facility at the University of Pretoria's Faculty of Veterinary Science at Onderstepoort. The isolation room has natural light and ambient temperature was maintained at $25^{\circ} \mathrm{C}$. Chicken and pigeon feed plus water was provided $a d$ libitum and was replenished at least once a day. Pigeons were fed a commercial pigeon ration of sunflower seed and maize. Chickens were provided with commercial pullet starter mash. Pigeon feed mixed with chicken feed was placed on the floor of the cages in stainless steel trays. Communal water was provided on the floor of the cage in 1 litre plastic bell drinkers.

\subsection{Virus}

The challenge virus, A/Speckled pigeon/South Africa/08-004B/2017 (H5N8) was isolated at the University of Pretoria from a dead Speckled pigeon (Columba guinea), sampled at a commercial chicken outbreak site on 14 August 2017 in the Ekurhuleni district, Gauteng Province. Phylogenetically, the virus is representative of the Clade 2.3.4.4 HPAI H5N8 Group B viruses that caused poultry outbreaks in the northern regions of South Africa from June to August 2017 (Abolnik et al., 2018). Passage 2 seed stock of the challenge virus was propagated in SPF embryonated chicken eggs according to the OIE recommended method (OIE, 2015). The 50\% embryo infectious dose $\left(\mathrm{EID}_{50}\right)$ of a third passage stock was determined through titration (Reed \& Muench, 1938) to be $10^{7.5} \mathrm{EID}_{50} / 0.1 \mathrm{ml}$ and was aliquotted and stored frozen at $-80^{\circ} \mathrm{C}$. Just prior to use, the titrated stock was thawed and diluted in OculoNasal diluent (Intervet). 


\subsection{Experimental design}

Eighteen pigeons were randomly divided into three treatment groups in separate cages of six pigeons each. Each pigeon received $0.06 \mathrm{ml}$ of inoculum intranasally (two drops, one per nostril). The low challenge dose group received $10^{3} \mathrm{EID}_{50}$; the medium challenge dose group was inoculated with $10^{4.5} \mathrm{EID}_{50}$ and the third group received the highest dose of $10^{6} \mathrm{EID}_{50}$. Three days later, another six non-challenged contact control pigeons and two SPF chickens were introduced randomly into each cage. The birds were monitored daily for illness or death. To assess viral shedding, Copan Ultra-thin minitip FLOQSwabs ${ }^{\mathrm{TM}}$ were used to swab the orpopharynx and cloaca of all birds in each cage at 2, 4, 6, 8, 10, 12 and 14 days post challenge (dpc). Dpc refers to the challenge date of the challenged pigeons throughout this study. Swabs were placed into $1 \mathrm{ml}$ of viral transport medium that consisted of brain-heart broth, $0.1 \mathrm{mg} / \mathrm{ml}$ doxycycline, $0.1 \mathrm{mg} / \mathrm{ml}$ enrofloxacin, $1 \mathrm{mg} / \mathrm{ml}$ penicillin-streptomycin and $10 \%$ glycerol and were frozen at $-80^{\circ} \mathrm{C}$ until testing. Pigeons and chickens were bled preplacement, at 8 days post challenge and at 14 days post challenge. At each collection, approximately 0.3 to $0.5 \mathrm{ml}$ of blood was taken from each bird by puncture of the wing vein with sterile a $21 \mathrm{G}$ needle. At $14 \mathrm{dpc}$ all birds were euthanized by cervical dislocation. All animal procedures were approved by the University of Pretoria's Animal Ethics Committee.

\subsection{Virus detection and quantification}

Two methods of RNA extraction were used; total RNA was first extracted from $200 \mu 1$ of swab fluid using a Roche MAgNaPure high-throughput robotic extraction system, with a $100 \mu 1$ elution volume (Agricultural Research Council- Onderstepoort Veterinary Research facility). RNA extractions were later repeated using TRIzolTM reagent (Invitrogen, ThermoFisher Scientific) according to the recommended procedure, with the modification of snipping the tip of the FLOQ swab off into the tube containing $250 \mu \mathrm{L}$ of swab fluid and $750 \mu 1$ of TRIzol, followed by vigorous vortexing to release maximum viral particles and lyse 
the viral membranes. The pelleted RNA was reconstituted in $50 \mu 1$ of nuclease-free ultra-pure water and stored at $-80^{\circ} \mathrm{C}$ until testing.

Extracted total RNAs were tested for the presence of the influenza A virus -specific RNA (vRNA) by quantitative revere transcription real-time PCR. To improve the detection of South African Clade 2.3.4.4 H5 outbreak strains, the probes and primers for the European Union-recommended method (Slomka et al, 2007) were customised as follows (underlined):

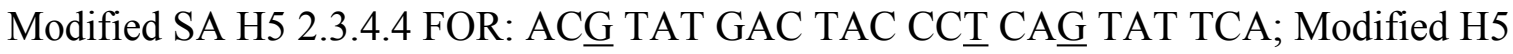

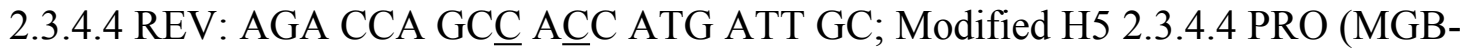
FAM): TCA ACA GTG GCG AGT TCC CTA GCA. The modifications allowed more specific binding to H5 vRNA, and therefore the assay is more sensitive for local strains than the standard EU method (validation data not shown). Three microliters of each sample or controls were tested in $12 \mu 1$ total volumes with VetMAX-Plus Multiplex One Step RT-PCR kits (Thermo Fisher Scientific), in a StepOnePlus Real-Time PCR System (Life Technologies) according to the following profile: 1 cycle of $48^{\circ} \mathrm{C}$ for $10 \mathrm{~min}, 1$ cycle of $95^{\circ} \mathrm{C}$ for $10 \mathrm{~min}, 40 \mathrm{cycles}$ of $95^{\circ} \mathrm{C}$ for $15 \mathrm{sec}, 53^{\circ} \mathrm{C}$ for $45 \mathrm{sec}$ (data capture point). Cycle threshold $(\mathrm{Ct})$ values above 40 were considered negative (i.e. H5 influenza vRNA not detected). For quantification, a standard curve was generated from 10-fold serial dilutions of vRNA extracted from the EID $_{50}$-titrated challenge virus. The limit of detection was determined by further serial dilution experiments to be $10^{0.08}$ EID $_{50}$ viral RNA copies.

\subsection{ELISA}

Pigeon and chicken sera were tested for the presence of anti-influenza virus nucleoprotein (NP) antibodies using IDEXX Influenza A Ab ELISA kits, according to the kit protocol. Sample to Negative $(\mathrm{S} / \mathrm{N})$ values were calculated from the A650 measurements. In avian species $\mathrm{S} / \mathrm{N}$ values above or equal to 0.5 are negative whereas $\mathrm{S} / \mathrm{N}$ values below 0.5 are positive. 


\section{RESULTS}

No clinical signs were observed in any pigeons or chickens in either the low, medium or high challenge dose groups over the 14-day duration of the trial (Table 1).

In the low challenge dose group that received only $10^{3} \mathrm{EID}_{50}$, a very low amount of viral RNA $\left(10^{0.82} \mathrm{EID}_{50}\right)$ was detected in the oropharyngeal swab of a single pigeon at $2 \mathrm{dpc}$ (Tables 1 and 2, Supplementary table 1). Neither this bird (\#A637) nor any other pigeon or chicken in the cage seroconverted (data not shown).

Comparatively more virus was detected in more birds that received the medium challenge dose, where virus was detected from $4 \mathrm{dpc}$ in the oropharyngeal swabs of 2/6 pigeons challenged with the $10^{4.5} \mathrm{EID}_{50}$ dose, as well as $3 / 6$ contact pigeons and one of the chickens (Table 1, Table 2). By 6 dpc, 4/6 challenged pigeons were shedding virus from both the oropharynx and the cloaca in amounts that ranged up to $10^{3.81} \mathrm{EID}_{50}$, and vRNA was also detected in 1/6 contact pigeons and 3/6 contact pigeons in the oropharynx and cloaca, respectively. The medium challenge dose group's median titers (Table 2) show that oropharyngeal shedding in both the challenged and contact pigeons peaked at $4 \mathrm{dpc}$ (median $10^{3.08}$ EID $_{50}$; Fig. 2a) and that cloacal shedding, although much lower, peaked at $6 \mathrm{dpc}\left(10^{0.63}\right.$ EID $_{50}$; Fig 2b). No virus was detected in this group from $8 \mathrm{dpc}$ onward, and no birds in the group seroconverted. A single challenged pigeon (\#B613) (Fig 2; supplementary Table 2) tested positive for a comparatively high amount of $10^{3.81} \mathrm{EID}_{50}$ at $4 \mathrm{dpc}$ in the oropharyngeal swab, but by $6 \mathrm{dpc}$ the levels were only $10^{1.54} \mathrm{EID}_{50}$, and no cloacal shedding was detected in this bird on subsequent days (Supplementary Table 2).

The highest vRNA titers were detected in the birds challenged with the highest dose of H5N8 virus. vRNA was detected at 2 dpc in the oropharynx of all challenged pigeons (Table 2) and in the cloaca in 3/6 of the challenged pigeons. A single challenged pigeon, \#C652 yielded a 
Table 1. Experimental outcome of birds challenged with Clade 2.3.4.4 HPAI H5N8

\begin{tabular}{|c|c|c|c|c|c|c|c|c|c|c|c|}
\hline \multirow{2}{*}{$\begin{array}{c}\text { Challenge dose } \\
\text { group }\end{array}$} & \multirow[t]{2}{*}{ Species } & \multirow[t]{2}{*}{ Morbidity } & \multirow[t]{2}{*}{ Mortality } & \multicolumn{7}{|c|}{ Viral RNA detection } & \multirow[t]{2}{*}{ NP ELISA } \\
\hline & & & & $2 \mathrm{dpc}$ & $4 \mathrm{dpc}$ & $6 \mathrm{dpc}$ & $8 \mathrm{dpc}$ & $10 \mathrm{dpc}$ & $\begin{array}{c}12 \\
\text { dpc }\end{array}$ & $14 \mathrm{dpc}$ & \\
\hline \multirow{6}{*}{$\begin{array}{c}\text { Low: } \\
10^{3} \mathrm{EID}_{50}\end{array}$} & Challenged pigeons & $0 / 6$ & $0 / 6$ & $1 / 6^{\mathrm{OP}}$ & $0 / 6^{\mathrm{OP}}$ & $0 / 6^{\mathrm{OP}}$ & $0 / 6^{\mathrm{OP}}$ & $0 / 6^{\mathrm{OP}}$ & $0 / 6^{\mathrm{OP}}$ & $0 / 6^{\mathrm{OP}}$ & $0 / 6$ \\
\hline & & & & $0 / 6^{\mathrm{CL}}$ & $0 / 6^{\mathrm{CL}}$ & $0 / 6^{\mathrm{CL}}$ & $0 / 6^{\mathrm{CL}}$ & $0 / 6^{\mathrm{CL}}$ & $0 / 6^{\mathrm{CL}}$ & $0 / 6^{\mathrm{CL}}$ & \\
\hline & Contact pigeons & $0 / 6$ & $0 / 6$ & & $0 / 6^{\mathrm{OP}}$ & $0 / 6^{\mathrm{OP}}$ & $0 / 6^{\mathrm{OP}}$ & $0 / 6^{\mathrm{OP}}$ & $0 / 6^{\mathrm{OP}}$ & $0 / 6^{\mathrm{OP}}$ & $0 / 6$ \\
\hline & & & & & $0 / 6^{\mathrm{CL}}$ & $0 / 6^{\mathrm{CL}}$ & $0 / 6^{\mathrm{CL}}$ & $0 / 6^{\mathrm{CL}}$ & $0 / 6^{\mathrm{CL}}$ & $0 / 6^{\mathrm{CL}}$ & \\
\hline & Contact chickens & $0 / 2$ & $0 / 2$ & & $0 / 2^{\mathrm{OP}}$ & $0 / 2^{\mathrm{OP}}$ & $0 / 2^{\mathrm{OP}}$ & $0 / 2^{\mathrm{OP}}$ & $0 / 2^{\mathrm{OP}}$ & $0 / 2^{\mathrm{OP}}$ & $0 / 2$ \\
\hline & & & & & $0 / 2^{\mathrm{CL}}$ & $0 / 2^{\mathrm{CL}}$ & $0 / 2^{\mathrm{CL}}$ & $0 / 2^{\mathrm{CL}}$ & $0 / 2^{\mathrm{CL}}$ & $0 / 2^{\mathrm{CL}}$ & \\
\hline \multirow{6}{*}{$\begin{array}{l}\text { Medium: } \\
10^{4.5} \mathrm{EID}_{50}\end{array}$} & Challenged pigeons & $0 / 6$ & $0 / 6$ & $0 / 6^{\mathrm{OP}}$ & $2 / 6^{\mathrm{OP}}$ & $4 / 6^{\mathrm{OP}}$ & $0 / 6^{\mathrm{OP}}$ & $0 / 6^{\mathrm{OP}}$ & $0 / 6^{\mathrm{OP}}$ & $0 / 6^{\mathrm{OP}}$ & $0 / 6$ \\
\hline & & & & $0 / 6^{\mathrm{CL}}$ & $1 / 6^{\mathrm{CL}}$ & $4 / 6^{\mathrm{CL}}$ & $0 / 6^{\mathrm{CL}}$ & $0 / 6^{\mathrm{CL}}$ & $0 / 6^{\mathrm{CL}}$ & $0 / 6^{\mathrm{CL}}$ & \\
\hline & Contact pigeons & $0 / 6$ & $0 / 6$ & & $3 / 6^{\mathrm{OP}}$ & $1 / 6^{\mathrm{OP}}$ & $0 / 6^{\mathrm{OP}}$ & $0 / 6^{\mathrm{OP}}$ & $0 / 6^{\mathrm{OP}}$ & $0 / 6^{\mathrm{OP}}$ & $0 / 6$ \\
\hline & & & & & $0 / 6^{\mathrm{CL}}$ & $3 / 6^{\mathrm{CL}}$ & $0 / 6^{\mathrm{CL}}$ & $0 / 6^{\mathrm{CL}}$ & $0 / 6^{\mathrm{CL}}$ & $0 / 6^{\mathrm{CL}}$ & \\
\hline & Contact chickens & $0 / 2$ & $0 / 2$ & & $1 / 2^{\mathrm{OP}}$ & $0 / 2^{\mathrm{OP}}$ & $0 / 2^{\mathrm{OP}}$ & $0 / 2^{\mathrm{OP}}$ & $0 / 2^{\mathrm{OP}}$ & $0 / 2^{\mathrm{OP}}$ & $0 / 2$ \\
\hline & & & & & $0 / 2^{\mathrm{CL}}$ & $0 / 2^{\mathrm{CL}}$ & $0 / 2^{\mathrm{CL}}$ & $0 / 2^{\mathrm{CL}}$ & $0 / 2^{\mathrm{CL}}$ & $0 / 2^{\mathrm{CL}}$ & \\
\hline \multirow{6}{*}{$\begin{array}{l}\text { High: } \\
10^{6} \mathrm{EID}_{50}\end{array}$} & Challenged pigeons & $0 / 6$ & $0 / 6$ & $6 / 6^{\mathrm{OP}}$ & $5 / 6^{\mathrm{OP}}$ & $6 / 6^{\mathrm{OP}}$ & $3 / 6^{\mathrm{OP}}$ & $0 / 6^{\mathrm{OP}}$ & $0 / 6^{\mathrm{OP}}$ & $0 / 6^{\mathrm{OP}}$ & $2 / 6^{\ddagger}$ \\
\hline & & & & $3 / 6^{\mathrm{CL}}$ & $6 / 6^{\mathrm{CL}}$ & $6 / 6^{\mathrm{CL}}$ & $4 / 6^{\mathrm{CL}}$ & $0 / 6^{\mathrm{CL}}$ & $0 / 6^{\mathrm{CL}}$ & $0 / 6^{\mathrm{CL}}$ & \\
\hline & Contact pigeons & $0 / 6$ & $0 / 6$ & & $5 / 6^{\mathrm{OP}}$ & $5 / 6^{\mathrm{OP}}$ & $1 / 6^{\mathrm{OP}}$ & $0 / 6^{\mathrm{OP}}$ & $0 / 6^{\mathrm{OP}}$ & $0 / 6^{\mathrm{OP}}$ & $0 / 6$ \\
\hline & & & & & $4 / 6^{\mathrm{CL}}$ & $3 / 6^{\mathrm{CL}}$ & $1 / 6^{\mathrm{CL}}$ & $0 / 6^{\mathrm{CL}}$ & $0 / 6^{\mathrm{CL}}$ & $0 / 6^{\mathrm{CL}}$ & \\
\hline & Contact chickens & $0 / 2$ & $0 / 2$ & & $0 / 2^{\mathrm{OP}}$ & $2 / 2^{\mathrm{OP}}$ & $1 / 2^{\mathrm{OP}}$ & $0 / 2^{\mathrm{OP}}$ & $0 / 2^{\mathrm{OP}}$ & $0 / 2^{\mathrm{OP}}$ & $0 / 2$ \\
\hline & & & & & $0 / 2^{\mathrm{CL}}$ & $0 / 2^{\mathrm{CL}}$ & $0 / 2^{\mathrm{CL}}$ & $0 / 2^{\mathrm{CL}}$ & $0 / 2^{\mathrm{CL}}$ & $0 / 2^{\mathrm{CL}}$ & \\
\hline
\end{tabular}

dpc-days post challenge; OP- oropharyngeal; CL-cloacal; ${ }^{\ddagger} \mathrm{AIV}$-specific antibodies detected at both 7 and 14 dpc 
Table 2: Log10 EID50 PCR equivalents/ viral genome copies per ml of birds challenged with Clade 2.3.4.4 A/Speckled pigeon/South Africa/08-004B/2017 (H5N8)

\begin{tabular}{|c|c|c|c|c|c|c|c|c|c|}
\hline \multicolumn{2}{|c|}{ Challenge dose } & \multicolumn{2}{|c|}{2 days post challenge } & \multicolumn{2}{|c|}{4 days post challenge } & \multicolumn{2}{|c|}{6 days post challenge } & \multicolumn{2}{|c|}{8 days post challenge } \\
\hline & & Range & Median & Range & Median & Range & Median & Range & Median \\
\hline Low & Challenged pigeons & $0-0.82^{\mathrm{OP}}$ & - & - & - & - & - & - & - \\
\hline \multirow[t]{5}{*}{$10^{3} \mathrm{EID}_{50}$} & & - & - & - & - & - & - & - & - \\
\hline & Contact pigeons & & & - & - & - & - & - & - \\
\hline & & & & - & - & - & - & - & - \\
\hline & Contact chickens & & & - & - & - & - & - & - \\
\hline & & & & - & - & - & - & - & - \\
\hline \multirow{6}{*}{$\begin{array}{l}\text { Medium } \\
10^{4.5} \mathrm{EID}_{50}\end{array}$} & Challenged pigeons & - & - & $0-3.81^{\mathrm{OP}}$ & $3.03^{\mathrm{OP}}$ & $0-1.70^{\mathrm{OP}}$ & $1.42^{\mathrm{OP}}$ & - & - \\
\hline & & - & - & $0-0.43^{\mathrm{CL}}$ & $-0.35^{\mathrm{CL}}$ & $0-1.54^{\mathrm{CL}}$ & $0.63^{\mathrm{CL}}$ & - & - \\
\hline & Contact pigeons & & & $0-1.08^{\mathrm{OP}}$ & $0.51^{\mathrm{OP}}$ & $0-0.43^{\mathrm{OP}}$ & $-1.15^{\mathrm{OP}}$ & - & - \\
\hline & & & & - & - & $0-1.10^{\mathrm{CL}}$ & $0.63^{\mathrm{CL}}$ & - & - \\
\hline & Contact chickens & & & $0-0.73^{\mathrm{OP}}$ & $0.42^{\mathrm{OP}}$ & - & - & - & - \\
\hline & & & & & - & - & - & - & - \\
\hline \multirow{6}{*}{$\begin{array}{l}\text { High } \\
10^{6} \mathrm{EID}_{50}\end{array}$} & Challenged pigeons & $0-5.59^{\mathrm{OP}}$ & $4.81^{\mathrm{OP}}$ & $0-2.61^{\mathrm{OP}}$ & $2.06^{\mathrm{OP}}$ & $0.60-2.07^{\mathrm{OP}}$ & $1.79^{\mathrm{OP}}$ & $0-1.75^{\mathrm{OP}}$ & $1.31^{\mathrm{OP}}$ \\
\hline & & $0-2.88^{\mathrm{CL}}$ & $2.15^{\mathrm{CL}}$ & $1.63-2.99^{\mathrm{CL}}$ & $2.46^{\mathrm{CL}}$ & $1.15-1.91^{\mathrm{CL}}$ & $1.66^{\mathrm{CL}}$ & $0-1.78^{\mathrm{CL}}$ & $1.51^{\mathrm{CL}}$ \\
\hline & Contact pigeons & & & $0-2.51^{\mathrm{OP}}$ & $2.16^{\mathrm{OP}}$ & $0-1.85^{\mathrm{OP}}$ & $1.53^{\mathrm{OP}}$ & $0-1.56^{\mathrm{OP}}$ & $0.77^{\mathrm{OP}}$ \\
\hline & & & & $0-1.88^{\mathrm{CL}}$ & $1.41^{\mathrm{CL}}$ & $0-2.11^{\mathrm{CL}}$ & $1.61^{\mathrm{CL}}$ & $0-1.64^{\mathrm{CL}}$ & $0.86^{\mathrm{CL}}$ \\
\hline & Contact chickens & & & - & - & $1.30-1.48^{\mathrm{OP}}$ & $1.40^{\mathrm{OP}}$ & $0-1.17^{\mathrm{OP}}$ & $0.86^{\mathrm{OP}}$ \\
\hline & & & & - & - & - & - & - & - \\
\hline \multirow[t]{2}{*}{$10^{6} \mathrm{EID}_{50}$} & Challenged chickens & $6.06-7.5^{\mathrm{OP}}$ & $7.17^{\mathrm{OP}}$ & $\dagger$ & & & & & \\
\hline & $(n=10)$ & $5.19-6.12^{\mathrm{CL}}$ & $5.92^{\mathrm{CL}}$ & & & & & & \\
\hline
\end{tabular}

OP oropharyngeal; ${ }^{\mathrm{CL}}$ cloacal; †all birds dead; ${ }^{*}$ Separate unpublished study, University of Pretoria 


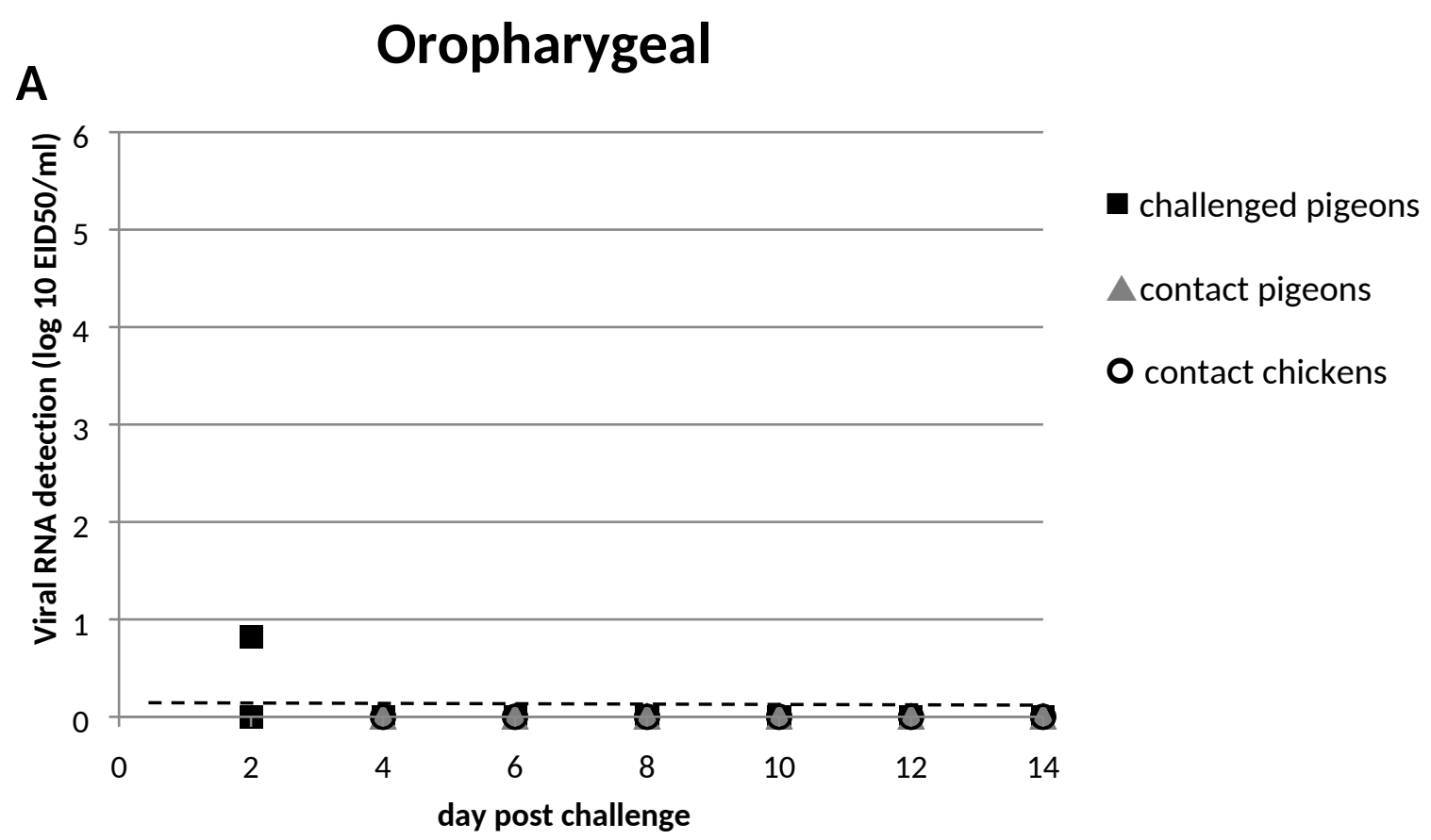

Cloacal

B

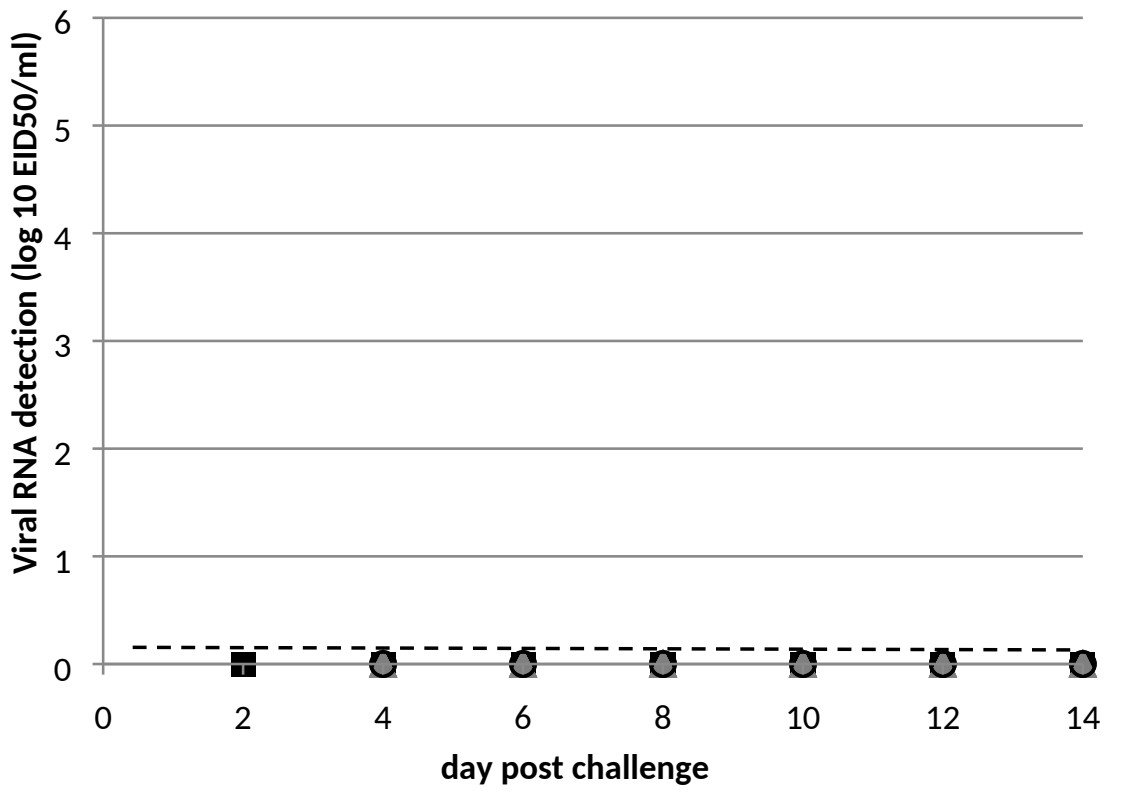

challenged pigeons

$\Delta$ contact pigeons

O contact chickens

Figure 1. Scatterplot of viral RNA detection by qRRT-PCR on (A) oropharyngeal and (B) cloacal swabs taken from birds inoculated with low $\left(10^{3} \mathrm{EID}_{50}\right)$ doses of A/Speckled pigeon/South Africa/08-004B/2017 (H5N8). The limit of detection for the H5N8 virus was $10^{0.08} \mathrm{EID}_{50} / \mathrm{ml}$ (dotted line). 


\section{A Oropharyngeal}

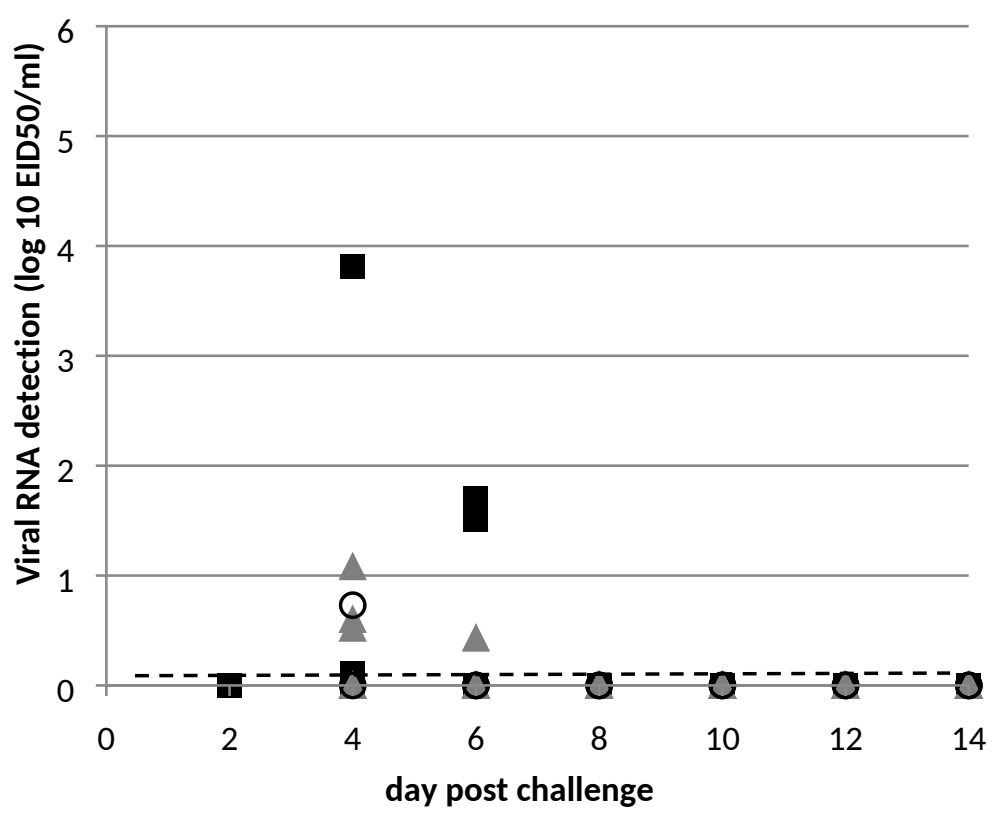

- challenged pigeons

$\triangle$ contact pigeons

O contact chickens

\section{B}

\section{Cloacal}

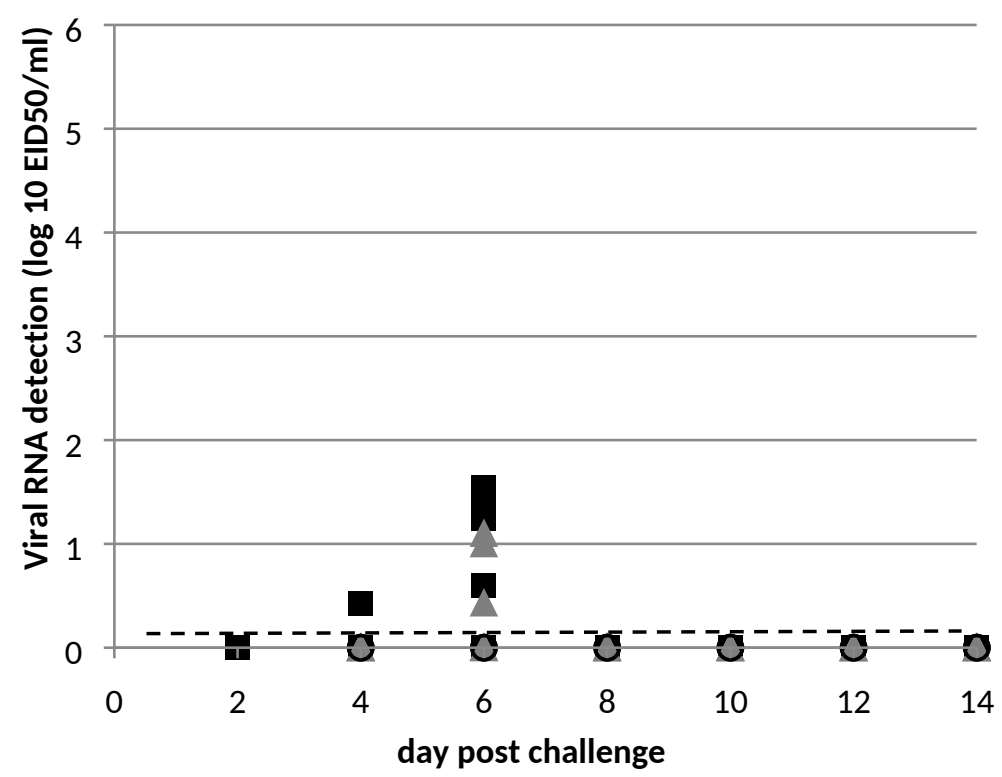

challenged pigeons

$\triangle$ contact pigeons

O contact chickens

Figure 2. Scatterplot of viral RNA detection by qRRT-PCR on (A) oropharyngeal and (B) cloacal swabs taken from birds inoculated with medium $\left(10^{4.5} \mathrm{EID}_{50}\right)$ doses of $\mathrm{A} /$ Speckled pigeon/South Africa/08-004B/2017 (H5N8). The limit of detection for the H5N8 virus was $10^{0.08} \mathrm{EID}_{50} / \mathrm{ml}$ (dotted line). 
titer of $10^{5.59} \mathrm{EID}_{50}$ (Supplementary Table 3), but it is possible that residual challenge material resulted in the strong PCR signal. At $4 \mathrm{dpc}$, most of the challenge and contact pigeons were shedding virus from the oropharynx as well as the cloaca (Table 2). Assessment of the median titers indicate that in challenged pigeons, shedding peaked at $4 \mathrm{dpc}$ in both the oropharynx (Fig 3a; mean titer $10^{2.06} \mathrm{EID}_{50}$ ) and in the cloaca (Fig 3b; mean titer $10^{2.46}$ EID $_{50}$ ), but in contact pigeons, whereas shedding also peak at $4 \mathrm{dpc}$ in the oropharynx (Fig 3a; mean titer $10^{2.16} \mathrm{EID}_{50}$ ) the peak cloacal shedding was detected at $6 \mathrm{dpc}$ (Fig $3 \mathrm{~b}$; mean titer $10^{1.61} \mathrm{EID}_{50}$ ). vRNA was still detected at $8 \mathrm{dpc}$ in both challenged and contact pigeons, where $3 / 6$ challenged pigeons still shed virus from the oropharynx and 4/6 from the cloaca, and 1/6 contact pigeons each shed virus from the oropharynx or cloaca (Table 1;

Supplementary Table 3). No viral RNA was detected from $10 \mathrm{dpc}$. Two pigeons in the challenge group, C652 and C686, seroconverted with influenza virus NP-specific antibodies detected at both $8(\mathrm{~S} / \mathrm{N}$ values of 0.14 and 0.39 respectively) and $14 \mathrm{dpc}(\mathrm{S} / \mathrm{N}$ values of 0.39 and 0.36 respectively).

At 6 and 8 dpc, vRNA was detected only in the oropharyngeal swabs of $2 / 2$ and $1 / 2$ contact chickens, respectively. It is likely that the detected vRNA in these swabs as well as those collected from chickens in the medium dose group at $4 \mathrm{dpc}$ reflects virus recently ingested from the contaminated environment, and not necessarily active shedding due to infection. No shedding from the cloaca of chickens was detected in any group, and neither did any chicken seroconvert. Chickens are highly susceptible to HPAI H5N8, and the pathogenicity of the challenge strain used in this study was previously established in SPF chickens infected by the ocular route, where the birds exhibited typical clinical signs and, shed virus in the order between $10^{6.04} \mathrm{EID}_{50}$ and $10^{7.5} \mathrm{EID}_{50}$ from oral swabs and between $10^{5.2}$ and $10^{6.2} \mathrm{EID}_{50}$ from cloacal swabs at 2DPC, and all birds had died by 3 dpc (Table 2; unpublished data). 


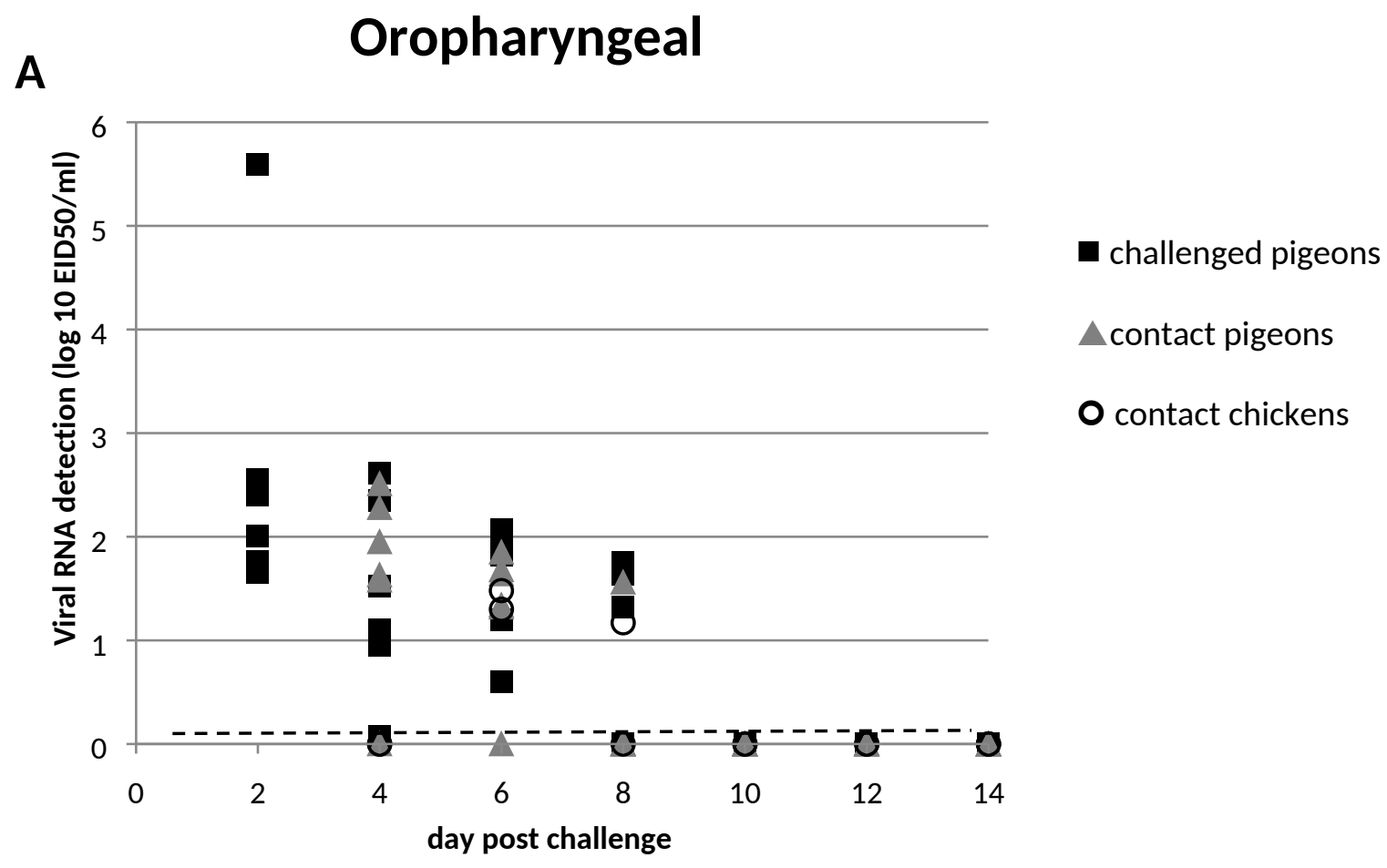

B

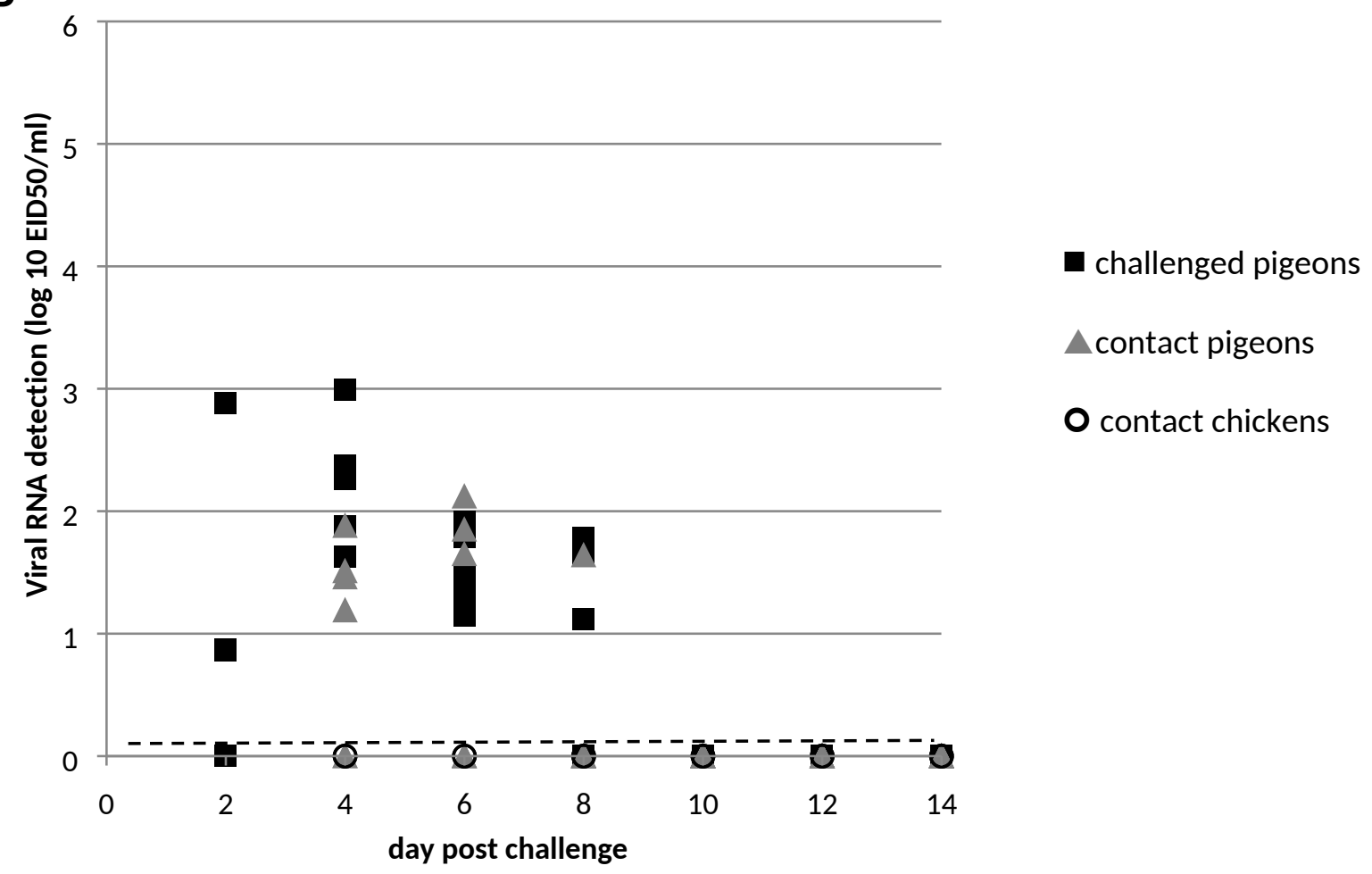

Figure 3. Scatterplot of viral RNA detection by qRRT-PCR on (A) oropharyngeal and (B) cloacal swabs taken from birds inoculated with high $\left(10^{6} \mathrm{EID}_{50}\right)$ doses of A/Speckled pigeon/South Africa/08-004B/2017 (H5N8). The limit of detection for the H5N8 virus was $10^{0.08} \mathrm{EID}_{50} / \mathrm{ml}$ (dotted line). 


\section{DISCUSSION}

Reports of large die-offs of wild pigeons and doves during the Clade 2.3.4.4 HPAI H5N8 outbreaks in South Africa in 2017, in which at least thirteen birds tested PCR positive for the virus, prompted us to investigate the pathogenicity to pigeons of a recent outbreak strain. Different H5 viruses have distinctive biological properties, and only two previous studies have assessed the pathogenicity and transmissibility of Clade 2.3.4.4 H5Nx viruses in pigeons. Kwon et al (2017) assessed two H5N8 strains, a sub-group icA3 H5N8 virus and a sub-group A H5N8 virus (Kandeil et al., 2017) and Xiang et al (2017) assessed a sub-group C H5N6 strain, whereas we used a Clade 2.3.4.4 H5N8 strain of the B sub-group.

No clinical signs or mortalities were observed in any of the birds over the duration of the study. Infection was only established in pigeons with the medium $\left(10^{4.5} \mathrm{EID}_{50}\right)$ and high $\left(10^{6}\right.$ $\mathrm{EID}_{50}$ ) challenge doses. In spite of a low rate of seroconversion, we found that both challenged and contact pigeons became infected but shed low levels of virus $\left(<10^{3} \mathrm{EID}_{50}\right)$ from the oropharynx and cloaca, with shedding peaking around $4 \mathrm{dpc}$ and lasting up until 8dpc. Kwon et al (2017) reported shedding of up to $10^{5.62} \mathrm{EID}_{50}$ in the oropharynx of $1 / 5$ pigeons challenged with a sub-group A strain, and $10^{5.28} \mathrm{EID}_{50}$ in the cloaca of $1 / 5$ pigeons challenged with the sub-group icA3 H5N8 virus. The challenge dose in that study was however $10^{7} \mathrm{EID}_{50}$. Perhaps the higher shedding in the prior study was due to strain differences, but other studies have shown that the dose of the virus is an important factor in determining susceptibility to Gs/Gd/96 lineage viruses in pigeons (Brown et al., 2009). Under natural conditions pigeons can inhale virus through aerosolized matter, ingest in contaminated drinking water and ingest through contaminated feed, or through preening feathers, roosting in contaminated feces or bathing in contaminated water. Beyond the artificial routes of challenge typically used in experimental infections, whether natural 
ingestion or inhalation by a pigeon of a dose equivalent of $10^{7} \mathrm{EID}_{50}$ is possible remains experimentally undetermined.

The levels of virus shed into the shared environment by the infected pigeons were insufficient to infect contact SPF chickens, indeed the levels of virus shed by the racing pigeons were well below experimentally-determined bird infectious dose $50\left(\mathrm{BID}_{50}\right)$ values for most poultry species, especially for chickens, where $10^{3.5}$ to $10^{5.7} \mathrm{EID}_{50}$ has been required for infection of depending on the strain of the Clade 2.3.4.4 H5 virus and the chicken breed (Tanikawa et al., 2016; Bertran et al., 2016a; Bertran et al., 2016b; Bertran et al., 2017; Pantin-Jackman et al., 2017; Spackman et al., 2017). Nonetheless, the low viral levels excreted from challenged pigeons appeared sufficient to infect in-contact pigeons. This finding suggests that pigeons are susceptible to low level of a sub-population of pigeonadapted viruses that are not infective for other avian species. Indeed, inter-host population bottlenecks for influenza A viruses that additionally are affected by the route of transmission have been experimentally demonstrated for mammalian influenza viruses (Varble et al., 2014), but similar experiments have not yet been conducted for inter-avian transmission of avian influenza strains.

Neither Xiang et al (2017) not Kwon et al (2017) were able to detect infection in contact pigeons, however in the former study, shedding was assessed by culture in embryonated chicken eggs. Propagation in ovo was demonstrated to enforce a population bottleneck on mammalian-adapted influenza A virus (Varble et al., 2014), therefore we can speculate that the sub-population of pigeon-adapted viruses may not have easily infected the chicken embryos. The failure of Kwon and coworkers to detect virus in contact pigeons might be due to the lower detection limit of the PCR they employed. In our study, we were able to detect very low amounts of vRNA because firstly the primers and probes were optimally matched to the challenge virus and secondly, we modified the RNA extraction procedure to concentrate 
the amount of vRNA. In fact, very few of the positive samples were detected tested positive with the original high throughput MagNAPure method tested positive (data not shown).

The low serological response of pigeons to $\mathrm{H} 5$ challenge, even in birds receiving the high challenge dose, is in line with prior studies (Abolnik, 2014, Kwon et al., 2017; Xiang et al., 2017). It was previously suggested that the resistance of pigeons and doves to HPAI stems from robust local cell-mediated and humoral $(\operatorname{IgA})$ immune responses in the mucosa that may be very effective in clearing the infection in pigeons, lessening the dependency and role of developing serum antibodies (Teske et al., 2013).

We did not assess systemic infection here but previous studies demonstrated the presence of virus in multiple tissues of challenged pigeons that were clinically-healthy (Kwon et al., 2017; Xiang et al., 2017). The detection of H5N8 virus in tissues of dead pigeons and doves during the 2017/2018 outbreaks may therefore have been incidental. In hindsight, the mortalities in pigeons and doves in $2017 / 2018$ in South Africa were more likely caused by a concurrent outbreak of Avian Avulavirus (formerly pigeon paramyxovirus, i.e. Newcastle disease) (Roberts, 2018), since dead pigeons and doves were not tested for both viruses. Alternatively, H5N8-related death could have occurred if pigeons had inhaled or ingested excessive amounts of virus from the environment or were immune-suppressed due to concurrent infections with other pathogens. In conclusion ultimately our results reiterate those of numerous previous studies with $\mathrm{Gs} / \mathrm{Gd} / 95 \mathrm{H} 5$ lineage strains that racing pigeons are susceptible to infection with HPAI H5 viruses, but excluding their potential role in fomite spread, are unlikely to contribute to the maintenance of the virus or transmission to other species.

\section{Conflict of interest}

None 


\section{Acknowledgements}

This study was funded by the National Research Foundation of South Africa (NRF) South African Research Chair Initiative (SARChI) Grant No. 114612. Racing pigeons and cages were kindly supplied by Mr Corrie Naude. Thandeka Phiri and Karen Ebershohn are thanked for technical assistance. 


\section{REFERENCES}

Abolnik, C. 2014. A current review of avian influenza in pigeons and doves (Columbidae).

Vet Microbiol. 170(3-4):181-196.

Abolnik, C., Pieterse, R., Peyrot, B.M., Choma, P., Phiri ,T.P., Ebersohn, K., van Heerden, C.J., Vorster, A.A., van der Zel, G., Geertsma, P.J., Laleye, A.T., Govindasamy, K., Rauff, D.L. 2018. The incursion and spread of HPAI H5N8 Clade 2.3.4.4 within South Africa. Avian Diseases, in press.

Bertran, K., Swayne, D.E., Pantin-Jackwood, M.J., Kapczynski, D.R., Spackman, E., Suarez, D.L. 2016(a). Lack of chicken adaptation of newly emergent Eurasian H5N8 and reassortant H5N2 high pathogenicity avian influenza viruses in the U.S. is consistent with restricted poultry outbreaks in the Pacific flyway during 2014-2015. Virology. 494:190-197.

Bertran, K., Lee, D.H., Balzli, C., Pantin-Jackwood, M.J., Spackman, E., Swayne, D.E. 2016(b). Age is not a determinant factor in susceptibility of broilers to H5N2 clade 2.3.4.4 high pathogenicity avian influenza virus. Vet Res. 47(1):116.

Bertran, K., Lee, D.H., Pantin-Jackwood, M.J., Spackman, E., Balzli, C., Suarez, D.L., Swayne, D.E. 2017. Pathobiology of Clade 2.3.4.4 H5Nx High-Pathogenicity Avian Influenza Virus Infections in Minor Gallinaceous Poultry Supports Early Backyard Flock Introductions in the Western United States in 2014-2015. J Virol. 291(21).

Brown, J.D., Stallknecht, D.E., Berghaus, R.D., Swayne, D.E. 2009. Infectious and lethal doses of H5N1 highly pathogenic avian influenza virus for house sparrows (Passer domesticus) and rock pigeons (Columbia livia). J Vet Diagn Invest. 21(4):437-445. 
Davids, T., Louw, M., Scheltema, N., Smi,t A. 2018. Bureau for Food and Agricultural Policy (BFAP). Economic impact of the 2017 Highly Pathogenic Avian Influenza outbreak in South Africa: A report by BFAP to the South African Poultry Association.

Kandeil, A., Kayed, A., Moatasim, Y., Webby, R.J., McKenzie, P.P., Kayali, G., Ali, M.A.2017. Genetic characterization of highly pathogenic avian influenza A H5N8 viruses isolated from wild birds in Egypt. J Gen Virol. 98(7):1573-1586.

Kang, H-M., Lee, E-K., Song, B-M., Heo, G-B., Jung, J., Jang, I., Bae, Y-C., Jung, S.C., Lee, Y-J. 2017. Experimental infection of mandarin duck with highly pathogenic avian influenza A (H5N8 and H5N1) viruses. Veterinary Microbiology 198: 59-63.

Kwon, J.H., Noh, Y.K., Lee, D.H., Yuk, S.S., Erdene-Ochir, T.O., Noh, J.Y., Hong,W.T., Jeong, J.H., Jeong, S., Gwon, G.B., Song, C.S., Nahm, S.S. 2017. Experimental infection with highly pathogenic H5N8 avian influenza viruses in the Mandarin duck (Aix galericulata) and domestic pigeon (Columba livia domestica). Vet Microbiol. 203:95-102.

Lee, D-H., Kwon, J-H., Noh, J-Y., Park, J-K., Yuk, S-S., Erdene-Ochir, T-O., Lee, J-B., Park, S-Y., Choi, I-S., Lee, S-W., Song, C-S. 2016a. Pathogenicity of the Korean H5N8 highly pathogenic avian influenza virus in commercial domestic poultry species. Avian Pathol 45 (2), 208-211.

Lee, E-K., Song, B-M., Kang, H-M., Woo, S-H., Heo, G-B., Jung, S-C., Park, Y-H., Lee, YJ., Kim, J.H. 2016b. Experimental infection of SPF and Korean native chickens with highly pathogenic avian influenza virus (H5N8). Poultry Science 95: 1015-1019.

OIE. 2015. Manual of Diagnostic tests and Vaccines for Terrestrial Animals. Chapter 2.3.4Avian Influenza, accessible at: http://www.oie.int/fileadmin/Home/eng/Health_standards/tahm/2.03.04_AI.pdf 
OIE. 2018. Summary of Immediate notifications and Follow-ups, Highly pathogenic influenza A viruses (infection with) (non-poultry including wild birds). Accessed at http://www.oie.int/wahis_2/public/wahid.php/Diseaseinformation/Immsummary

Pantin-Jackwood, M.J., Costa-Hurtado, M., Bertran, K., DeJesus, E., Smith, D., Swayne, D.E. 2017. Infectivity, transmission and pathogenicity of H5 highly pathogenic avian influenza clade 2.3.4.4 (H5N8 and H5N2) United States index viruses in Pekin ducks and Chinese geese. Vet Res. 48(1):33.

Reed, L.J., Muench, H. 1938. A simple method for estimating fifty per cent endpoints. American Journal of Epidemiology, 27(3): 493-497.

Roberts, L. 2018. Highly Pathogenic Avian Influenza (H5N8 subtype) in Coastal Birds in South Africa. Western Cape Department of Agriculture. Status update 20 May 2018.

Sims, L.D., Harder, T., Brown, I., Gaidet, N., Belot, G., von Dobschuetz, S., Kamata, A., Kivaria, F., Palamara, E., Bruni, M., Dauphin, G., Raizman, E., \& Lubroth, J. 2017. Highly pathogenic H6 avian influenza in 2016 and 2017- observations and future perspectives. EMPRES Focus On, No. 11, Nov 2017, Rome.

Slomka, M.J., Pavlidis, T., Banks, J., Shell, W., McNally, A., Essen, S., Brown, I.H. 2007. Validated H5 Eurasian real-time reverse transcriptase-polymerase chain reaction and its application in H5N1 outbreaks in 2005-2006. Avian Dis. 51(1 Suppl): 373-377.

Spackman, E., Prosser, D.J., Pantin-Jackwood, M.J., Berlin, A.M., Stephens, C.B. 2017. The pathogenesis of clade 2.3.4.4 H5 highly pathogenic avian influenza viruses in Ruddy duck (Oxyura jamaicensis) and Lesser Scaup (Aythya affinis). J Wildl Dis. 53(4): 832-842. 
Teske, L., Ryll, M., Rautenschlein, S.2013. Epidemiological investigations on the role of clinically healthy racing pigeons as a reservoir for avian paramyxovirus-1 and avian influenza virus. Avian Pathol. 42(6):557-565.

Tanikawa, T., Kanehira, K., Tsunekuni, R., Uchida, Y., Takemae, N., Saito, T. 2016. Pathogenicity of H5N8 highly pathogenic avian influenza viruses isolated from a wild bird fecal specimen and a chicken in Japan in 2014. Microbiol Immunol. 60(4):243-252.

Varble, A., Albrecht, R.A., Backes, S., Crumiller, M., Bouvier, N.M., Sachs, D., GarcíaSastre, A., tenOever, B.R. 2014. Influenza A virus transmission bottlenecks are defined by infection route and recipient host. Cell Host Microbe. 16(5):691-700.

WHO/OIE/FAO. 2012. Continued evolution of highly pathogenic avian influenza A(H5N1): Updated nomenclature. Influenza and Other Respiratory Viruses 6(1), 1-5.

Xiang, B., Liang, J., You, R., Han, L., Mei, K., Chen, L., Chen, R., Zhang, Y., Dai, X., Gao, P., Liao, M., Xiao, C., Ren, T. 2017. Pathogenicity and transmissibility of a highly pathogenic avian influenza virus H5N6 isolated from a domestic goose in Southern China. Vet Microbiol. 212:16-221. 


\section{Supplementary Material}

Supplementary Table 1 . Low challenge dose group $\mathrm{EID}_{50}$ PCR equivalents/ viral genome copies per $\mathrm{ml}\left(\log _{10}\right.$ EID $_{50}$ PCR equivalents)

\begin{tabular}{|c|c|c|c|c|c|c|c|c|}
\hline & Bird no. & $2 \mathrm{dpc}$ & $4 \mathrm{dpc}$ & $6 \mathrm{dpc}$ & $8 \mathrm{dpc}$ & $10 \mathrm{dpc}$ & $12 \mathrm{dpc}$ & 14 dpc \\
\hline \multirow{12}{*}{ 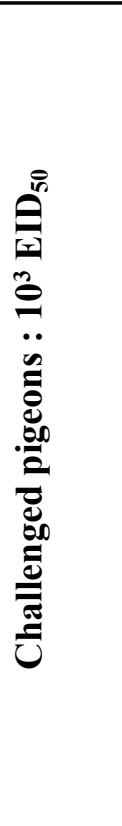 } & $\mathrm{A} 643 \mathrm{O}$ & 0 & 0 & 0 & 0 & 0 & 0 & 0 \\
\hline & $\mathrm{A} 643 \mathrm{C}$ & 0 & 0 & 0 & 0 & 0 & 0 & 0 \\
\hline & $\mathrm{A} 637 \mathrm{O}$ & $6.67(0.82)$ & 0 & 0 & 0 & 0 & 0 & 0 \\
\hline & $\mathrm{A} 637 \mathrm{C}$ & 0 & 0 & 0 & 0 & 0 & 0 & 0 \\
\hline & $\mathrm{A} 640 \mathrm{O}$ & 0 & 0 & 0 & 0 & 0 & 0 & 0 \\
\hline & $\mathrm{A} 640 \mathrm{C}$ & 0 & 0 & 0 & 0 & 0 & 0 & 0 \\
\hline & A636O & 0 & 0 & 0 & 0 & 0 & 0 & 0 \\
\hline & $\mathrm{A} 636 \mathrm{C}$ & 0 & 0 & 0 & 0 & 0 & 0 & 0 \\
\hline & $\mathrm{A} 608 \mathrm{O}$ & 0 & 0 & 0 & 0 & 0 & 0 & 0 \\
\hline & $\mathrm{A} 608 \mathrm{C}$ & 0 & 0 & 0 & 0 & 0 & 0 & 0 \\
\hline & A645O & 0 & 0 & 0 & 0 & 0 & 0 & 0 \\
\hline & $\mathrm{A} 645 \mathrm{C}$ & 0 & 0 & 0 & 0 & 0 & 0 & 0 \\
\hline \multirow{12}{*}{ 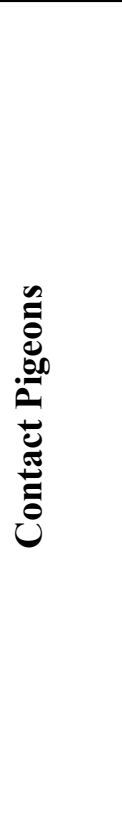 } & A611O & & 0 & 0 & 0 & 0 & 0 & 0 \\
\hline & A611C & & 0 & 0 & 0 & 0 & 0 & 0 \\
\hline & $\mathrm{A} 684 \mathrm{O}$ & & 0 & 0 & 0 & 0 & 0 & 0 \\
\hline & $\mathrm{A} 684 \mathrm{C}$ & & 0 & 0 & 0 & 0 & 0 & 0 \\
\hline & $\mathrm{A} 632 \mathrm{O}$ & & 0 & 0 & 0 & 0 & 0 & 0 \\
\hline & $\mathrm{A} 632 \mathrm{C}$ & & 0 & 0 & 0 & 0 & 0 & 0 \\
\hline & $\mathrm{A} 660 \mathrm{O}$ & & 0 & 0 & 0 & 0 & 0 & 0 \\
\hline & $\mathrm{A} 660 \mathrm{C}$ & & 0 & 0 & 0 & 0 & 0 & 0 \\
\hline & $\mathrm{A} 626 \mathrm{O}$ & & 0 & 0 & 0 & 0 & 0 & 0 \\
\hline & A626C & & 0 & 0 & 0 & 0 & 0 & 0 \\
\hline & $\mathrm{A} 692 \mathrm{O}$ & & 0 & 0 & 0 & 0 & 0 & 0 \\
\hline & $\mathrm{A} 692 \mathrm{C}$ & & 0 & 0 & 0 & 0 & 0 & 0 \\
\hline \multirow{4}{*}{ 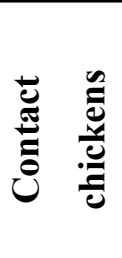 } & ARed O & & 0 & 0 & 0 & 0 & 0 & 0 \\
\hline & ARed C & & 0 & 0 & 0 & 0 & 0 & 0 \\
\hline & ABlack O & & 0 & 0 & 0 & 0 & 0 & 0 \\
\hline & ABlack C & & 0 & 0 & 0 & 0 & 0 & 0 \\
\hline
\end{tabular}

dpc- days post challenge; O-oropharyngeal swab; C-cloacal swab 
Supplementary Table 2. Medium challenge dose group $\mathrm{EID}_{50}$ PCR equivalents/ viral genome copies per $\mathrm{ml}\left(\log _{10} \mathrm{EID}_{50}\right.$ PCR equivalents)

\begin{tabular}{|c|c|c|c|c|c|c|c|c|c|}
\hline & & Bird no. & $2 \mathrm{dpc}$ & $4 \mathrm{dpc}$ & $6 \mathrm{dpc}$ & $8 \mathrm{dpc}$ & $10 \mathrm{dpc}$ & 12 dpc & $14 \mathrm{dpc}$ \\
\hline \multirow{12}{*}{\multicolumn{2}{|c|}{ 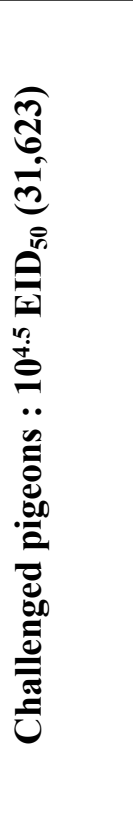 }} & B641O & 0 & 0 & $50(1.70)$ & 0 & 0 & 0 & 0 \\
\hline & & B641C & 0 & 0 & $17.34(1.24)$ & 0 & 0 & 0 & 0 \\
\hline & & $\mathrm{B} 642 \mathrm{O}$ & 0 & $1.3(0.11)$ & $41.33(1.62)$ & 0 & 0 & 0 & 0 \\
\hline & & B642C & 0 & 0 & $26(1.41)$ & 0 & 0 & 0 & 0 \\
\hline & & $\mathrm{B} 623 \mathrm{O}$ & 0 & 0 & $32.68(1.51)$ & 0 & 0 & 0 & 0 \\
\hline & & B623C & 0 & $2.67(0.43)$ & $34.66(1.54)$ & 0 & 0 & 0 & 0 \\
\hline & & B613O & 0 & $6435.08(3.81)$ & $34.66(1.54)$ & 0 & 0 & 0 & 0 \\
\hline & & B613C & 0 & 0 & 0 & 0 & 0 & 0 & 0 \\
\hline & & B6910 & 0 & 0 & 0 & 0 & 0 & 0 & 0 \\
\hline & & B691C & 0 & 0 & 0 & 0 & 0 & 0 & 0 \\
\hline & & $\mathrm{B} 672 \mathrm{O}$ & 0 & 0 & 0 & 0 & 0 & 0 & 0 \\
\hline & & B672C & 0 & 0 & $4.0(0.60)$ & 0 & 0 & 0 & 0 \\
\hline \multirow{12}{*}{\multicolumn{2}{|c|}{ 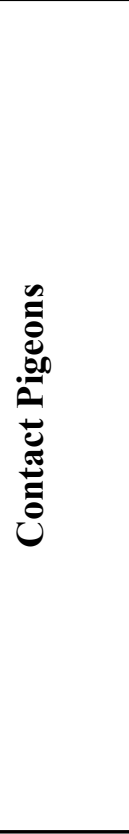 }} & $\mathrm{B} 625 \mathrm{O}$ & & $4.0(0.60)$ & 0 & 0 & 0 & 0 & 0 \\
\hline & & B625C & & 0 & 0 & 0 & 0 & 0 & 0 \\
\hline & & $\mathrm{B} 690 \mathrm{O}$ & & $3.33(0.52)$ & 0 & 0 & 0 & 0 & 0 \\
\hline & & B690C & & 0 & 0 & 0 & 0 & 0 & 0 \\
\hline & & $\mathrm{B} 662 \mathrm{O}$ & & $12(1.08)$ & 0 & 0 & 0 & 0 & 0 \\
\hline & & B662C & & 0 & 0 & 0 & 0 & 0 & 0 \\
\hline & & B667O & & 0 & 0 & 0 & 0 & 0 & 0 \\
\hline & & B667C & & 0 & $10.0(1.00)$ & 0 & 0 & 0 & 0 \\
\hline & & B663O & & 0 & 0 & 0 & 0 & 0 & 0 \\
\hline & & B663C & & 0 & $2.67(0.43)$ & 0 & 0 & 0 & 0 \\
\hline & & B622O & & 0 & $2.67(0.43)$ & 0 & 0 & 0 & 0 \\
\hline & & B622C & & 0 & $12.67(1.10)$ & 0 & 0 & 0 & 0 \\
\hline \multirow{4}{*}{\multicolumn{2}{|c|}{ 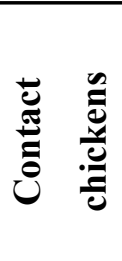 }} & BRed O & & $5.33(0.73)$ & 0 & 0 & 0 & 0 & 0 \\
\hline & & BRed C & & 0 & 0 & 0 & 0 & 0 & 0 \\
\hline & & BBlack O & & 0 & 0 & 0 & 0 & 0 & 0 \\
\hline & & BBlack C & & 0 & 0 & 0 & 0 & 0 & 0 \\
\hline
\end{tabular}

DPC- Days post challenge; O-oropharyngeal swab; C-cloacal swab 
Supplementary Table 3. High challenge dose group $\operatorname{EID}_{50}$ PCR equivalents/ viral genome copies per ml $\left(\log _{10} \operatorname{EID}_{50}\right.$ PCR equivalents)

\begin{tabular}{|c|c|c|c|c|c|c|c|c|}
\hline & Bird no. & 2 DPC & 4 DPC & 6 DPC & 8 DPC & 10 DPC & 12 DPC & 14 DPC \\
\hline \multirow{12}{*}{ 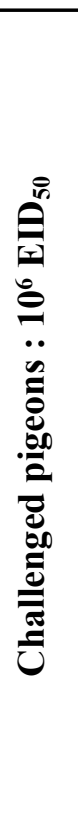 } & $\mathrm{C} 656 \mathrm{O}$ & $102.66(2.01)$ & 0 & $66.00(1.82)$ & $44.00(1.64)$ & 0 & 0 & 0 \\
\hline & C656C & $7.33(0.86)$ & $187.32(2.27)$ & $61.33(1.79)$ & 0 & 0 & 0 & 0 \\
\hline & $\mathrm{C} 652 \mathrm{O}$ & $386097.88(5.59)$ & $409.32(2.61)$ & $68.00(1.83)$ & 0 & 0 & 0 & 0 \\
\hline & C652C & $766.64(2.88)$ & $42.66(1.63)$ & $14.00(1.15)$ & $44.00(1.64)$ & 0 & 0 & 0 \\
\hline & C619O & $57.33(1.76)$ & $8.67(0.95)$ & $4.00(0.60)$ & 0 & 0 & 0 & 0 \\
\hline & C619C & 0.00 & $75.33(1.88)$ & $81.33(1.91)$ & $53.33(1.73)$ & 0 & 0 & 0 \\
\hline & C6810 & $354.65(2.55)$ & $33.33(1.52)$ & $97.29(1.99)$ & $56.66(1.75)$ & 0 & 0 & 0 \\
\hline & C681C & $77.33(0.87)$ & $987.96(2.99)$ & $72.66(1.86)$ & $13.33(1.12)$ & 0 & 0 & 0 \\
\hline & C648O & $250.66(2.40)$ & $12.67(1.10)$ & $16.00(1.20)$ & $20.67(1.32)$ & 0 & 0 & 0 \\
\hline & C648C & 0.00 & $235.30(2.37)$ & $28.65(1.46)$ & $60.00(1.78)$ & 0 & 0 & 0 \\
\hline & $\mathrm{C} 686 \mathrm{O}$ & $45.32(1.66)$ & $222.66(2.35)$ & $117.32(2.07)$ & 0 & 0 & 0 & 0 \\
\hline & C686C & 0.00 & $182.66(2.26)$ & $19.33(1.29)$ & $46.67(1.67)$ & 0 & 0 & 0 \\
\hline \multirow{7}{*}{ 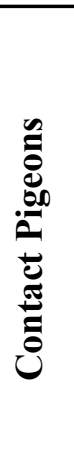 } & C629O & & $192.00(2.28)$ & 0.00 & 0 & 0 & 0 & 0 \\
\hline & C629C & & $32.66(1.51)$ & 0.00 & 0 & 0 & 0 & 0 \\
\hline & $\mathrm{C} 671 \mathrm{O}$ & & $42.66(1.63)$ & $22.00(1.34)$ & $36.00(1.56)$ & 0 & 0 & 0 \\
\hline & C671C & & $28.67(1.46)$ & 0.00 & 0 & 0 & 0 & 0 \\
\hline & $\mathrm{C} 649 \mathrm{O}$ & & 0.00 & $20.66(1.32)$ & 0 & 0 & 0 & 0 \\
\hline & C649C & & $76.00(1.88)$ & $44.66(1.65)$ & 0 & 0 & 0 & 0 \\
\hline & $\mathrm{C} 631 \mathrm{O}$ & & 88.67 (1.95) & $43.33(1.64)$ & 0 & 0 & 0 & 0 \\
\hline
\end{tabular}




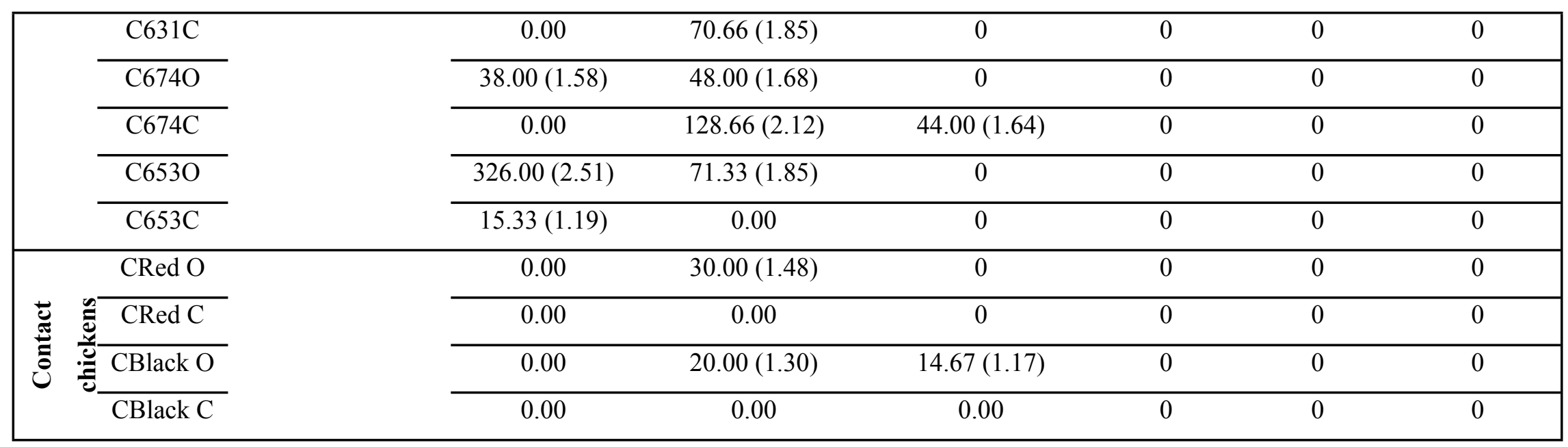

DPC- Days post challenge; O-oropharyngeal swab; C-cloacal swab 